\title{
O ACONTECIMENTO POR SLAVOJ ZIZEK
}

Leonardo Domingos Braga da Silva ${ }^{1}$

Zizek, S. O acontecimento: Uma viagem filosófica através de um conceito. Rio de janeiro: Zahar, 2017.

Slavoj Zizek tem sido um autor de destaque na discussão filosófica e política contemporânea. Na obra $O$ acontecimento o autor atualiza suas ideais em relação ao ponto central da noção de acontecimento, passando pela compreensão mais cotidiana até chegar à refinada filosoficamente, expondo os impasses de cada abordagem da noção. Como primeira definição, temos: "um acontecimento é, assim, o efeito que parece exceder suas causas - e o espaço de um acontecimento é aquele que é aberto pela brecha que separa o efeito das causas" (p.9). Assim, essa concepção vem romper com a metafísica tradicional segundo a qual tudo o que acontece deve estar vinculado a cadeias causais e razões suficientes sugerindo algo que acontece a partir do nada, tema já elaborado pelo autor na sua obra Menos que nada; (boitempo, 2013). O acontecimento é uma mudança no enquadramento pelo qual percebemos o mundo.

O autor separa a filosofia entre os polos: transcendental, do qual Kant e Heidegger são grandes representantes; e ontológico ou ôntico, do qual as ciências hoje tomam conta. O primeiro trata do arcabouço que "define as coordenadas da realidade" (p.10), enquanto o segundo se preocupa com a realidade em si em sua origem e configuração. Todavia, ambas abordagens levam a uma noção de acontecimento: o primeiro como a abertura do campo de significação que funda nossa percepção da realidade e o segundo como o big bang, um acontecimento que origina os entes. A abordagem transcendental, como lida por Zizek, encontra eco no pensamento de Lacan o inconsciente é "conhecimento simbolicamente articulado ignorado pelo sujeito (p.15)".

Conforme o autor, uma das reações ao trauma que é um acontecimento pode ser a fuga para a fantasia: "imaginar o mundo em si mesmo, fora de nosso horizonte subjetivo". A fantasia, mais do que realizar o desejo de forma alucinatória, funda esse desejo, estrutura-o e permite uma experiência fenomenal integrada num todo significativo. Atravessar a fantasia não é sair dela, mas reconhecer sua inconsistência. Por

1 Bacharel em sociologia pela UFRN e estudante de pós-graduação em filosofia (PPGFIL) pela mesma instituição. Email: leonardexistimans@live.com. http://orcid.org/0000-0003-3926-4321 
funcionar como pano de fundo onde a experiência aparece, ela perde sua força sobre o sujeito quando vista diretamente. A essência da técnica (gestell), como pensada por Heidegger, seria para Zizek uma fantasia que permite nossa exploração implacável da natureza, sua superação sendo a tomada consciência de que a técnica é um modo de enquadramento, nós a superamos.

No segundo capítulo Zizek apresenta o acontecimento cristão como culpa, queda. Se valendo de Kiekegaard, afirma que o cristianismo é a única religião acontecimental: "o único acesso ao absoluto se dá pela aceitação do acontecimento singular da encarnação como ocorrência histórica extraordinária” (p.41); cristo traz a boa nova de um rompimento radical, o acontecimento é então uma ruptura com o curso normal das coisas no milagre da ascensão de cristo.

O acontecimento cristão seria o oposto da iluminação budista por trazer a dissimulação e sofrimento. O budista veria a personalização, o ego, como uma divisão na unidade cósmica, uma queda que a iluminação visa corrigir. O cristianismo a veria como uma condição do bem, uma culpa feliz (felix culpa, título do capítulo). A queda e o ato de eva trazem a possibilidade da moral e ética, antes disso havia uma simples animalidade paradisíaca.

No terceiro capítulo, o budismo é retratado como complemento ao naturalismo científico, como meio para manter a aparência de sanidade e participar plenamente da dinâmica capitalista ao mesmo tempo. Segundo o autor, a neurociência e algumas filosofias insistem no fato de que o eu não existe, e o budismo seria um acontecimento que permite a experiência disso: uma acontecimentalização subjetiva do cognitivismo científico. O resultado fenomenal da neurociência é a iluminação: "a atitude de desapego e iluminação produz uma perfeita máquina de matar” (p.69). Há, pois, impasses no budismo, como sobre a decisão de ajudar outros a atingir a iluminação ou não, o que, Zizek pretende, mostra a impossibilidade de ficar livre da agência responsável e livre. Contra a fuga para a fantasia budista, que faz persistir a ilusão de nosso self ao observar a realidade de um suposto ponto de vista externo, Zizek afirma que o verdadeiro acontecimento é justamente "a própria subjetividade, ilusória como possa ser" (p.74).

Nos capítulos seguintes, Zizek aborda a noção de acontecimento na física quântica, que concebe o vácuo composto de uma virtualidade preontológica que quando tem sua simetria quebrada dá origem às possibilidades e entificações (o evento do big bang), e na filosofia. Conforme o autor, a filosofia tem em Platão, Decartes e Hegel, três 
acontecimentos e relações com ele. Platão trata do encontro traumático com o real da aparência, da configuração que por vezes pode ser mais real que a realidade. $\mathrm{O}$ absoluto aparece em momentos fugazes e frágeis. Decartes trás com o cogito a noção mesma de sujeito freudiano "um sujeito surge quando um indivíduo é privado de seu conteúdo substancial" (p.93). A personalidade, as emoções, habilidades etc, são uma imaginária substância do eu, enquanto o sujeito em seu nível zero é uma pura casca vazia. Hegel, por sua vez, insiste em que sem a ilusão não temos a verdade e cada ato é muito adiantado e muito atrasado, não havendo momento certo de agir. Em Hegel, tudo se torna acontecimental.

Zizek ainda trata do acontecimento na psicanálise, colocando os três registros da linguagem como três tipos dele: o real é o encontro absurdo com A Coisa fora do simbólico; o simbólico é a emergência de um novo significante mestre e da própria ordem simbólica; e o imaginário é um acontecimento sem substância, pura aparência.

Nos dois últimos capítulos o autor envolve mais diretamente o campo político, sendo provocativo: um acontecimento pode ser anulado, desacontecimentalizado e pode ser negado, não aceito. É o caso da constante mudança na realidade ôntica que muda para, paradoxalmente, permanecer a mesma. Por isso, e por fim, Zizek afirma que um autêntico acontecimento político é a critica a ideologia que, sem destruição material concreta, transforma inteiramente o campo simbólico, transforma o enquadramento a partir do qual vemos as coisas.

O livro vem trazer importantes críticas às posturas ideológicas como a da serenidade (gelassenheit) heideggeriana e budista ou abordagens despersonalizadas da realidade, sob perspectiva objetiva; bem como revitalizar a capacidade de ação política e o pensamento através de uma verdadeira assumpção do caráter acontecimental de certos eventos e da compreensão do enquadramento a que submetemos a realidade. A leitura da obra pode fazer alguns leitores pensarem que a atividade política da esquerda precisa mais do que nunca de um acontecimento, e esse livro de Zizek é um claro sintoma da incapacidade, da impossibilidade, dos impasses da esquerda contemporânea, cada vez mais incapaz de transformar a realidade deve esperar que o impossível aconteça ou fazer o impossível acontecer. De mãos atadas, agindo cedo de mais ou tarde de mais, sem saber as consequências de seus atos, o sujeito político contemporâneo é como o cogito cartesiano pensado pelo autor, um puro vazio de onde a ação parte, sem conteúdo substancial. Apenas quando esse caráter do sujeito político for assumido, apenas quando 
se evitar as diversas identificações, paixões, fantasias, ou as diversas certezas que o sujeito político tende a assumir, então estaremos abertos para um acontecimento. 